\title{
The nonenzymatic template-directed ligation of oligonucleotides
}

\author{
A. V. Lutay, E. L. Chernolovskaya, M. A. Zenkova, and V. V. Vlassov \\ Institute of Chemical Biology and Fundamental Medicine SB RAS, Lavrentiev Avenue 8, Novosibirsk 630090, Russia
}

Received: 4 October 2005 - Published in Biogeosciences Discuss.: 13 January 2006

Revised: 4 April 2006 - Accepted: 21 April 2006 - Published: 20 June 2006

\begin{abstract}
The nonenzymatic template-directed ligation of oligonucleotides containing $2^{\prime}, 3^{\prime}$-cyclic phosphate was investigated in the presence of divalent cations. Ligation of the oligonucleotides readily occurred in the presence of $\mathrm{Mg}^{2+}$, $\mathrm{Mn}^{2+}, \mathrm{Co}^{2+}, \mathrm{Zn}^{2+}, \mathrm{Pb}^{2+}$. Efficacy of the metal ion catalysts inversely correlated with pKa values of the metal-bound water molecules. The intermolecular transesterification reaction yielded at least $95 \%$ of $2^{\prime}, 5^{\prime}$-phosphodiester bonds independently on the nature of the metal ion. Relatively high reaction yields (up to 15\%) suggest, that RNA fragmentation to oligonucleotides with $2^{\prime}, 3^{\prime}$-cyclic phosphates, followed by reactions of those oligonucleotides could provide a source of new RNA molecules under prebiotic conditions.
\end{abstract}

\section{Introduction}

Spontaneous and random sequence rearrangements of RNA molecules, discovered recently by A. V. Chetverin, could play an important role in the development of prebiotic RNA World (Chetverin, 1999). The proposed mechanism of those rearrangements includes successive transesterification steps: cleavage and ligation reactions. The reactions can occur both in trans and in cis, and this may generate a variety of new RNA sequences. Inasmuch as the rearrangements require nothing but RNA itself and $\mathrm{Mg}^{2+}$, they must be ubiquitous in nature (Chetverin, 1999).

The cleavage/ligation reactions are hypothesized to play an important role in the early steps of RNA world development, providing a pathway to longer functionally active oligomers.

The intramolecular phosphoester transfer (cleavage) reaction of RNA molecule, resulting in the formation of the terminal $2^{\prime}, 3^{\prime}$-cyclophosphate and $5^{\prime}$-hydroxyl residues, oc-

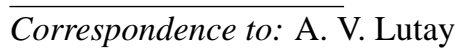

(lutay_av@niboch.nsc.ru) curs spontaneously and is accelerated by various chemical agents (Soukup et al., 1999). It is also known that a number of discovered catalytic nucleic acids operate with formation of $2^{\prime}, 3^{\prime}$-cyclic phosphate (Dahm et al., 1993; Hampel et al., 1997; Jeoung et al., 1994; Santoro et al., 1998). The reverse ligation reaction of oligonucleotides with $2^{\prime}, 3^{\prime}$-cyclic phosphate could proceed with $5^{\prime}$-hydroxyl group of different oligonucleotides what result in RNA molecules with new sequences.

Metal ions are known to catalyze reactions of the phosphodiester bonds. However, in contrast to the well-studied RNA cleavage reaction, catalyzed by metal ions, no systematic studies of metal ion catalysis of the reverse reaction ligation, occurring with $2^{\prime}, 3^{\prime}$-cyclic phosphate, have been reported.

It was shown that divalent metal ions accelerate the template-directed nonenzymatic ligation of two oligonucleotides possessing the terminal 5'-hydroxyl and 2',3'-cyclic phosphate (Flynn-Charlebois et al., 2003; Lutay et al., 2005).

Here we report the results of comparative study of different divalent metal ion's catalytic efficiency in that reaction. Since the investigated nonenzymatic ligation reaction has a linear kinetics during used time periods (4-5 days) and the yield of the product correlates with the rate (FlynnCharlebois et al., 2003), we use the term "catalysis" for description of the yield increase, obtained for determined time interval, meaning the increase of the ligation reaction rate.

\section{Materials and methods}

\subsection{Enzymes and chemicals}

$\left[\gamma-{ }^{32} \mathrm{P}\right]$ ATP (specific activity, $>3000 \mathrm{Ci} / \mathrm{mmol}$ ) was from Biosan Co (Russia). T4 DNA ligase and T4 polynucleotide kinase were purchased from Fermentas. RNase T1 was from Boehringer Mannheim. All buffers were prepared using

Published by Copernicus GmbH on behalf of the European Geosciences Union. 
MilliQ water and were filtered through $0.22 \mu \mathrm{m}$ Millipore filters.

\subsection{Oligonucleotides}

Oligonucleotides were synthesized using standard automated solid-phase methods. Templates: Tc - GCCGTATCATCTTTGGTGTTTCCTATCCCT, Tg - GCCGTATCATCTTTGCTGTTTCCTATCCCT and right-hand substrates: $\mathrm{R}_{15}$ - CAAAGATGATACGGC; $\mathrm{R}_{10}$ - CAAAGATGATA were purchased from Biosset Co. (Russia). Lefthand substrates precursors, containing $3^{\prime}$-ribonucleotides: Lc $^{\prime \prime}$ - AGGGATAGGAAACArCrA; Lg" - AGGGATAGGAAACArGrA were synthesized by Dr. M. Repkova (this institute). All labeled and unlabeled oligonucleotides were purified by electrophoresis in $20 \%$ polyacrylamide/ $7 \mathrm{M}$ urea gels (here and after d-PAGE) and stored at $-20^{\circ} \mathrm{C}$.

\section{$2.3 \quad 5^{\prime}-32 \mathrm{P}$-oligonucleotide labeling}

Oligonucleotides $\mathrm{Lc}^{\prime \prime}, \mathrm{Lg}^{\prime \prime}, \mathrm{L}_{10}$ were $5^{\prime}$ end labeled with ${ }^{32} \mathrm{P}$ using T4 polynucleotide kinase and $\left[\gamma^{3}{ }^{32} \mathrm{P}\right]$ ATP and purified in $20 \%$ d-PAGE.

\subsection{Alkaline cleavage of $\mathrm{Lc}^{\prime \prime}$ and $\mathrm{Lg}^{\prime \prime}$}

$0.1 \mathrm{nmol}$ of $5^{\prime}{ }^{32} \mathrm{P}-\mathrm{Lc}^{\prime \prime}$ or $\mathrm{Lg}^{\prime \prime}$ was incubated in $0.2 \mathrm{M} \mathrm{NaOH}$ for $20 \mathrm{~min}$ at $90^{\circ} \mathrm{C}$. After incubation, equal volume of $0.2 \mathrm{M} \mathrm{HCl}$ was added, and the oligonucleotide was precipitated with ethanol and then purified in 20\% d-PAGE to yield ${ }^{32} \mathrm{P}$-labeled $\mathrm{Lc} \mathrm{c}^{\prime}{ }^{32}$ pAGGGATAGGAAACArCp and $\mathrm{Lg}^{\prime}{ }^{-32}$ pAGGGATAGGAAACArGp, respectively.

2.5 Formation of oligonucleotides with 2/,3/-cyclic phosphates

${ }^{32} \mathrm{P}$-labeled left-hand substrates bearing $2^{\prime}, 3^{\prime}$-cyclic phosphate: Lc $-{ }^{32}$ pPAGGGATAGGAAACArC $>$ p, Lg ${ }^{32}$ pAGGGATAGGAAACArG $>p$ were prepared by incubating $1 \mathrm{nmol}$ of ${ }^{32} \mathrm{P}$-labeled $\mathrm{Lc}^{\prime}$ or $\mathrm{Lg}^{\prime}$ in $100 \mathrm{mM}$ MES-TEA buffer $\mathrm{pH} 5.5$, containing $50 \mathrm{mM}$ 1-ethyl-3-(3dimethylaminopropyl)carbodiimide hydrochloride for $1 \mathrm{~h}$ at $37^{\circ} \mathrm{C}$ (Hertel et al., 1994). 2',3'-cyclic phosphate formation was monitored by electrophoresis in $20 \%$ d-PAGE, using $\mathrm{Lc}^{\prime}$ and $\mathrm{Lg}^{\prime}$ as standard and by treatment of reaction products with $0.01 \mathrm{M} \mathrm{HCl}$ for $30 \mathrm{~min}$ at $37^{\circ} \mathrm{C}$ (conditions of $2^{\prime}, 3^{\prime}$ cyclic phosphate hydrolysis, Usher et al., 1976).

\subsection{Nonenzymatic ligation reaction}

To form the complementary complex, oligonucleotides $\mathrm{R}_{15}$, $5^{\prime}{ }^{32} \mathrm{P}-\mathrm{Lc}$ and Tc were mixed at concentration $30 \mu \mathrm{M}$ each in $5 \mathrm{mM}$ HEPES pH 7.0 buffer, supplemented with $200 \mathrm{mM}$ $\mathrm{NaCl}$. The mixture was heated at $40^{\circ} \mathrm{C}$ for $5 \mathrm{~min}$, slowly cooled down to $4^{\circ} \mathrm{C}$ and incubated for 3 days at $37^{\circ} \mathrm{C}$ in 50 $\mathrm{mM}$ Cacodylate buffer at $\mathrm{pH}$ 6.0, 6.4, 6.8 and 7.2 or Tris$\mathrm{HCl}$ buffer at $\mathrm{pH} 7.2,7.6,8.4$ and 8.8. The buffers contained
$200 \mathrm{mM} \mathrm{NaCl}$; concentration of divalent metal ions ranged from $50 \mathrm{nM}$ to $250 \mathrm{mM}$. Concentration of the complementary complex was $1 \mu \mathrm{M}$ in all reaction mixtures. After incubation, the probes were precipitated with ethanol, dissolved in the loading buffer (50\% formamide, $10 \mathrm{mM}$ EDTA pH 8.0, $0.005 \%$ bromophenol blue and $0.005 \%$ xylene cyanol) and resolved in 20\% d-PAGE.

\subsection{Visualization and quantification methods}

Visualization of the ${ }^{32} \mathrm{P}$-labeled substrates, complexes and products of reactions was accomplished by exposing dried gels on FX Imaging Screen overnight, scanning the screens on Molecular Imager FX-PRO Plus (Bio-Rad) with following quantification of the bands radioactivity using Quantity One v 4.2.3. software. Alternatively, the gel slices, corresponding to reaction products, were cut out of the gel and their radioactivity was measured by Cherenkov counting. The yield of the ligation reaction was calculated as the ratio of the radioactivity found in the band of the ligation product to the total radioactivity applied on the gel lane.

\subsection{Enzymatic synthesis of $3^{\prime}, 5^{\prime}$-containing ligation prod-} uct $\left(\mathrm{P}^{\prime}\right)$

$1 \mathrm{nmol}$ of $\mathrm{Lg}^{\prime}$ was incubated in $30 \mu \mathrm{l}$ reaction mixture, containing $10 \mathrm{mM}$ Tris- $\mathrm{HCl} \mathrm{pH} 7.8,0.5 \mathrm{mM} \mathrm{MgCl}_{2}$ and 2 units Calf intestine alkaline phosphatase for $2 \mathrm{~h}$ at $37^{\circ} \mathrm{C}$. Then, reaction mixture was extracted twice with $50 \mu \mathrm{l}$ of chloroform/isopropanol (29:1), oligonucleotides were precipitated with ethanol and dissolved in water.

To form complementary complex, $1 \mathrm{nmol}$ of resulted dephosphorylated oligonucleotide (AGGGATAGGAAACArG), $1 \mathrm{nmol}{ }^{32} \mathrm{P}$-labeled $\mathrm{R}_{10}$ and $1 \mathrm{nmol} \mathrm{Tg}$ were mixed in $20 \mu \mathrm{l}$ of water and dried on SpeedVac evaporator. Then, oligonucleotides were re-suspended in $30 \mu 1$ of $40 \mathrm{mM}$ Tris-HCl pH 7.8, containing $10 \mathrm{mM} \mathrm{MgCl}_{2}, 10 \mathrm{mM} \mathrm{DTT}$, $1 \mathrm{mM}$ ATP, $2 \mathrm{mM}$ spermidine, $1 \mu \mathrm{l}$ T4 DNA-ligase and reaction mixture was incubated for $20 \mathrm{~h}$ at $13^{\circ} \mathrm{C}$. Reaction was quenched by heating at $70^{\circ} \mathrm{C}$ for $10 \mathrm{~min}$, dried on SpeedVac evaporator, dissolved in $20 \mu 1$ of loading buffer and resolved in $20 \%$ d-PAGE. The ${ }^{32} \mathrm{P}$-labeled 25 -nt ligation product was eluted from the gel, precipitated with ethanol, re-precipitated and stored in water at $-20^{\circ} \mathrm{C}$.

\subsection{Preparation of nonenzymatic ligation product $(\mathrm{P})$}

Nonenzymatic ligation reactions were performed in $100 \mu \mathrm{l}$ reaction mixtures containing $1 \mathrm{nmol}$ of oligonucleotide complex $\left({ }^{32} \mathrm{pUg}: \mathrm{L}_{10}: \mathrm{Tg}=1: 1: 1\right)$ and $50 \mathrm{mM}$ buffer containing metal ions: (1) Tris- $\mathrm{HCl} \mathrm{pH} \mathrm{8.8,} 15 \mathrm{mM} \mathrm{MgCl}_{2}$; (2) Tris-HCl pH 8.4, $1 \mathrm{mM} \mathrm{MnCl}_{2}$; (3) Tris- $\mathrm{HCl} \mathrm{pH} \mathrm{7.2,} 5 \mathrm{mM} \mathrm{CoCl}_{2}$. Reaction mixtures were incubated for 3 days at $37^{\circ} \mathrm{C}$. The products of nonenzymatic ligation $(\mathrm{P})$ were isolated as described above. 
A

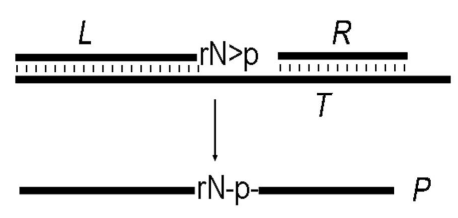

B

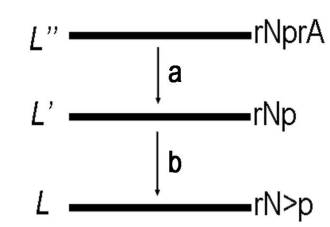

Fig. 1. (A) The oligonucleotide system used for investigation of the nonenzymatic ligation reaction. DNA is shown as a thick line, ribonucleotides are denoted by letters; $\mathrm{N}$ is $\mathrm{C}$ or $\mathrm{G}$, for the oligonucleotides Lc and Lg, respectively. (B) Scheme of preparation of oligonucleotide $\mathrm{L}$ with cyclic phosphate at the $3^{\prime}$-end. (A) Alkaline hydrolysis, (B) Carbodiimide-catalyzed cyclization.

\subsection{Alkaline hydrolysis of ligation products}

Oligonucleotides $\mathrm{P}$ and $\mathrm{P}^{\prime}(50000 \mathrm{cpm})$ were incubated in $0.2 \mathrm{M} \mathrm{NaOH}$ for $20 \mathrm{~min}$ at $90^{\circ} \mathrm{C}$, then neutralized with $1 / 10$ volume of $2 \mathrm{M} \mathrm{HCl}$, ethanol precipitated, dissolved in loading buffer and analyzed in $20 \%$ d-PAGE.

\subsection{Cleavage of ligation products with RNase T1}

Oligonucleotides $\mathrm{P}$ and $\mathrm{P}^{\prime}(50000 \mathrm{cpm})$ were incubated in $20 \mathrm{mM}$ Cacodylate buffer $\mathrm{pH} 6.8$ in the presence of 50 units of ribonuclease $\mathrm{T} 1$ for $6 \mathrm{~h}$ at $45^{\circ} \mathrm{C}$. After the incubation, oligonucleotides were precipitated with ethanol, dissolved in loading buffer and analyzed in 20\% d-PAGE.

\subsection{Hydrolysis of $2^{\prime}, 5^{\prime}$ and $3^{\prime}, 5^{\prime}$ phosphodiester bonds}

Oligonucleotides $\mathrm{P}$ and $\mathrm{P}^{\prime}(50000 \mathrm{cpm})$ were incubated in the absence and in the presence of the DNA-complement (1:1) in $50 \mathrm{mM}$ Tris-HCl $\mathrm{pH} 9.0$, containing $100 \mathrm{mM} \mathrm{Mg}^{2+}$ and $100 \mathrm{mM} \mathrm{NaCl}$ at $37^{\circ} \mathrm{C}$ for different time intervals. The aliquots were withdrawn from the reaction mixture, mixed with the loading buffer and applied on 15\% d-PAGE.

\section{Results}

\subsection{Metal ion catalysis of the nonenzymatic ligation}

The oligonucleotide complex investigated in this study is shown in Fig 1a. The "left-hand substrate" (L), hybridized to 30-nt DNA complement (T), contains $2^{\prime}, 3^{\prime}$-cyclic phosphate, which reacts with $5^{\prime}$-hydroxyl group of adjacent 10 nt oligonucleotide ("right-hand substrate" $\mathrm{R}_{15}$ ) to yield 25 nt ligation product. Two types of left-hand substrates Lc and $\mathrm{Lg}$, containing $2^{\prime}, 3^{\prime} \mathrm{C}>\mathrm{p}$ or $2^{\prime}, 3^{\prime} \mathrm{G}>\mathrm{p}$, and templates (Tc and $\mathrm{Tg}$ ) were used. The $2^{\prime}, 3^{\prime}$-cyclic phosphate at the $3^{\prime}$-end of oligonucleotide $\mathrm{Lc}^{\prime}$ (or $\mathrm{Lg}^{\prime}$ ) was formed with the use of the water-soluble carbodiimide as described in Materials and Methods (Fig. 1), and the yield was estimated at $98 \%$.

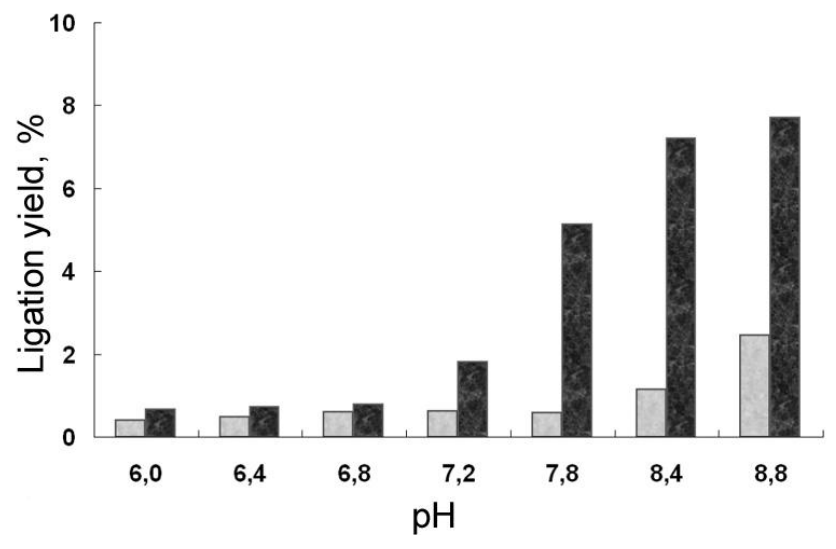

Fig. 2. pH Dependence of spontaneous (light bars) and metal catalyzed (dark bars) nonenzymatic oligonucleotide ligation. $1 \mu \mathrm{M}$ oligonucleotide complex $(\mathrm{T} / \mathrm{Lc}+\mathrm{R})$ was incubated in the absence or in the presence of $\mathrm{MgCl}_{2}(5 \mathrm{mM})$ in $50 \mathrm{mM}$ Cacodylate buffer containing $200 \mathrm{mM} \mathrm{NaCl}$ (pH 6.0, 6.4, 6.8, 7.2), or in $50 \mathrm{mM}$ Tris$\mathrm{HCl}$ buffer containing $200 \mathrm{mM} \mathrm{NaCl}(\mathrm{pH} 7.2,7.8,8.4,8.8)$ for 3 days at $37^{\circ} \mathrm{C}$. The ligation reaction yields at $\mathrm{pH} 7.2$ are averaged for Cacodylate and Tris- $\mathrm{HCl}$ buffers, since the difference between that values was less than the experimantal error $\sim 0,3 \%$ ).

The complementary complex containing template, righthand and left-hand substrates was formed by annealing of equimolar mixture of oligonucleotides $\mathrm{L}, \mathrm{R}_{15}$ and $\mathrm{T}$ in appropriate buffer, Tris- $\mathrm{HCl}$ or Cacodylate, containing $200 \mathrm{mM}$ $\mathrm{NaCl}$ (see Fig. 1 legend). At $30 \mu \mathrm{M}$ concentration of the oligonucleotides, quantitative complex formation was achieved (data not shown).

$\mathrm{pH}$-dependence of the ligation reaction catalyzed by $\mathrm{Mg}^{2+}$ is shown in Fig. 2. pH interval 6.0-8.8 was chosen, taking into account that the rate of $2^{\prime}, 3^{\prime}$-cyclic phosphate hydrolysis increases at $\mathrm{pH}<6$, and that spontaneous hydrolysis of phosphodiester bonds in RNA occurs at $\mathrm{pH}>9$. The reaction proceeded in Cacodylate and Tris buffers with similar efficiencies at $\mathrm{pH} 7.2(0.5$ vs. $0.6 \%$ and 1.5 vs. $1.7 \%$ in the absence and in the presence of $\mathrm{Mg}^{2+}$ ions, respectively). Efficiency of the ligation reaction increases within $\mathrm{pH}$ interval from 6.0 to 8.8 (Fig. 2).

We investigated the effect of $\mathrm{Mg}^{2+}, \mathrm{Mn}^{2+}, \mathrm{Co}^{2+}, \mathrm{Zn}^{2+}$, and $\mathrm{Pb}^{2+}$ ions on the ligation reaction performed in Tris$\mathrm{HCl}$ buffers at $\mathrm{pH} 7.2$ and $\mathrm{pH}$ 8.8. Results of the experiments are shown in Fig. 3. At pH 7.2 the dependences of the reaction yield on the tested ions concentration, except for $\mathrm{Mg}^{2+}$, are presented by one-maximum-shape curve, with maxima at: $25 \mathrm{mM}$ for $\mathrm{Mn}^{2+}, 0.5 \mathrm{mM}$ for $\mathrm{Pb}^{2+}$ and $5 \mathrm{mM}$ for $\mathrm{Co}^{2+}$ and $\mathrm{Zn}^{2+}$. Apparently, the maximal ligation yield was not achieved in the reaction mixture with $\mathrm{Mg}^{2+}$ ion under the experimental conditions. According to the maximal ligation yields observed at $\mathrm{pH} 7.2$ after 3 days incubation, metal ions can be placed in the order: $\mathrm{Pb}^{2+}(8 \%)>\mathrm{Mn}^{2+}(7 \%)>\mathrm{Zn}^{2+}=\mathrm{Co}^{2+}=\mathrm{Mg}^{2+}(6 \%)$. 


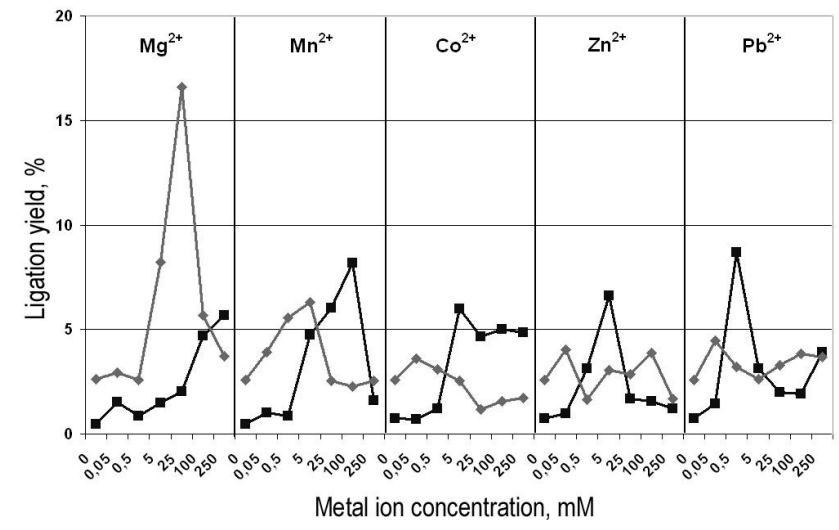

Fig. 3. The oligonucleotides ligation in the presence of metal ions at pH 7.2 (dark squares) and 8.8 (light rhombs). Experimental conditions: $1 \mu \mathrm{M}$ oligonucleotide complex $(\mathrm{T} / \mathrm{Lc}+\mathrm{R})$ was incubated in the presence of metal ions $(50 \mu \mathrm{M}-250 \mathrm{mM})$ in $50 \mathrm{mM}$ Tris- $\mathrm{HCl}$ buffer at $\mathrm{pH} 7.2$ and 8.8 , containing $200 \mathrm{mM} \mathrm{NaCl}$ for 3 days at $37^{\circ} \mathrm{C}$.

At $\mathrm{pH}$ 8.8, $\mathrm{pH}$-dependences curves with a maximum were observed only for $\mathrm{Mg}^{2+}$ and $\mathrm{Mn}^{2+}$ (at $25 \mathrm{mM}$ and $5 \mathrm{mM}$ for $\mathrm{Mg}^{2+}$ and $\mathrm{Mn}^{2+}$, respectively). In the presence of other metal ions ligation occurred rather poorly and no maxima on the concentration dependence curves were observed. The catalytic efficiencies of metal ions in nonenzymatic ligation at $\mathrm{pH} 8.8$ decreased in the order: $\mathrm{Mg}^{2+}$ $(16,5 \%)>>\mathrm{Mn}^{2+}(6,3 \%)>\mathrm{Co}^{2+}=\mathrm{Zn}^{2+}=\mathrm{Pb}^{2+}(<5 \%)$.

\subsection{Analysis of the ligation product}

$5^{\prime}$-hydroxyl group is capable of reacting with $2^{\prime}, 3^{\prime}$ cyclophosphate yielding ligation products, containing either $2^{\prime}, 5^{\prime}$ - or $3^{\prime}, 5^{\prime}$-phosphodiester bond. To investigate the product structure, left-hand substrate $\mathrm{Lg}^{\prime \prime}$ was used to yield the linkage $\mathrm{rGpN}$ which could be then exposed to the treatment by ribonuclease $\mathrm{T} 1$, selectively cleaving only $3^{\prime}-\mathrm{GpN}-5^{\prime}$ linkages. Complex of $\mathrm{Tg}, \mathrm{Lg}$ and $\mathrm{R}_{10}$ was incubated in the presence of three metal ions under following conditions: $15 \mathrm{mM}$ $\mathrm{Mg}^{2+} / \mathrm{pH} 8.8 ; 1 \mathrm{mM} \mathrm{Mn}^{2+} / \mathrm{pH} 8.4 ; 10 \mathrm{mM} \mathrm{Co}^{2+} / \mathrm{pH} 7.2$ at $37^{\circ} \mathrm{C}$ for $72 \mathrm{~h}$. Then ligation products were isolated and subjected to cleavage by RNase T1 and alkali in order to identify the type of ribolinkage formed. Ligation product $\mathrm{P}^{\prime}$, prepared from $5^{\prime}-{ }^{32} \mathrm{P}$-labeled right-hand substrate $\mathrm{R}_{10}$ and dephosphorylated left-hand substrate $\mathrm{Lg}$ by enzymatic ligation using $\mathrm{T} 4$ DNA ligase, was used as a positive control. The data are shown in Fig. 4.

It is seen that the products of the nonenzymatic ligation $\mathrm{P}(\mathrm{Me})$ and $3^{\prime}, 5^{\prime}$-containing ligation product $\mathrm{P}^{\prime}$ were completely cleaved by alkali (lanes 1). At pH $6.8(20 \mathrm{mM}$ Cacodylate- $\mathrm{HCl}$ buffer) all the ligation products remained intact for $6 \mathrm{~h}$ at $45^{\circ} \mathrm{C}$ (lanes 2). Under these conditions, RNase $\mathrm{T} 1$ cleaved completely the enzymatic ligation product $\mathrm{P}^{\prime}$ but no noticeable $(>5 \%)$ cleavage of the nonenzymatic ligation

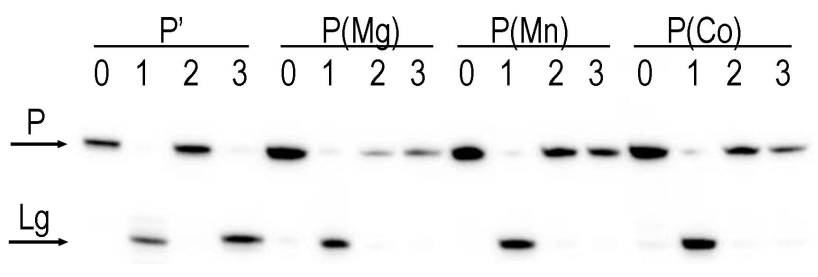

Fig. 4. Cleavage of phosphodiester bonds in $\mathrm{P}^{\prime}$ and $\mathrm{P}(\mathrm{Me})$. Metal ions used in the nonenzymatic ligation reactions are shown in parentheses. $\mathrm{P}^{\prime}$. the oligonucleotide produced by enzymatic ligation, containing only $3^{\prime}, 5^{\prime}$-bonds. 0 , intact ligation products; 1 , oligonucleotides, incubated in $0.2 \mathrm{M} \mathrm{NaOH}$ for $20 \mathrm{~min}$ at $90^{\circ} \mathrm{C}$; 2 , oligonucleotides, incubated in $20 \mathrm{mM}$ Cacodylate- $\mathrm{HCl}$ buffer $\mathrm{pH} 6.8$ for $6 \mathrm{~h}$ at $45^{\circ} \mathrm{C}$; 3 , oligonucleotides, incubated in the same conditions as in 2 , with addition of 50 units of ribonuclease $\mathrm{T} 1$.

products was observed (lanes 3). This result indicates that at least $95 \%$ of each nonenzymatic ligation product was linked by $2^{\prime}, 5^{\prime}$-bond.

In order to elucidate the isomeric type and stability of the phosphodiester bond formed in the nonenzymatic ligation reaction, we used the metal-catalyzed hydrolysis in mild alkaline conditions (see discussion). Nonenzymatic ligation products were incubated at $\mathrm{pH} 9.0$ in the presence of 100 $\mathrm{mM} \mathrm{Mg}^{2+}$ at $37^{\circ} \mathrm{C}$ for $48 \mathrm{~h}$. The $3^{\prime}, 5^{\prime}$-linked control ligation product $\mathrm{P}^{\prime}$ was incubated under similar conditions (Fig. 5). $3^{\prime}, 5^{\prime}$-bond containing product remained $95 \%$ intact by the end of incubation and the presence of its complement provided almost complete protection (see Fig. 5, panels a and c). In contrast, $85 \%$ of the nonenzymatic ligation product $\mathrm{P}(\mathrm{Mg})$ was cleaved under the same conditions, and its stability decreased in the presence of its complement Tg (see Figs. 5b and $5 \mathrm{~d}$, respectively). Secondary plot of the data, presented in Fig. 5a, is shown in Fig. 5b and the cleavage rate constants calculated using first-order kinetic equation are listed in the figure legend.

The obtained rates of nonenzymatic ligation product $\mathrm{P}$ hydrolysis in the single and in the double strand are approximately $10^{3}$ times higher than that for the enzymatic ligation product $\mathrm{P}^{\prime}$. Placing the $3^{\prime}, 5^{\prime}$-RNA linkage in the context of a double helix decreased its hydrolysis rate by a factor of ten, whereas nonenzymatic ligation product $\mathrm{P}$ was cleaved in the presence of its complement 1.5 times faster. These results are consistent with the reported instability of $2^{\prime}, 5^{\prime}$-RNA linkages within double helix, compared to $3^{\prime}, 5^{\prime}$-phosphodiester bonds (Rohatgi et al., 1996; Usher et al., 1976).

\section{Discussion}

\subsection{Catalysis of ligation reaction by divalent metal ions}

The spontaneous ligation reaction within the complex shown in Fig. 1 in the absence of divalent metal ions demonstrated an escalating $\mathrm{pH}$ - yield profile (Fig. 2), which suggests base 
A

B

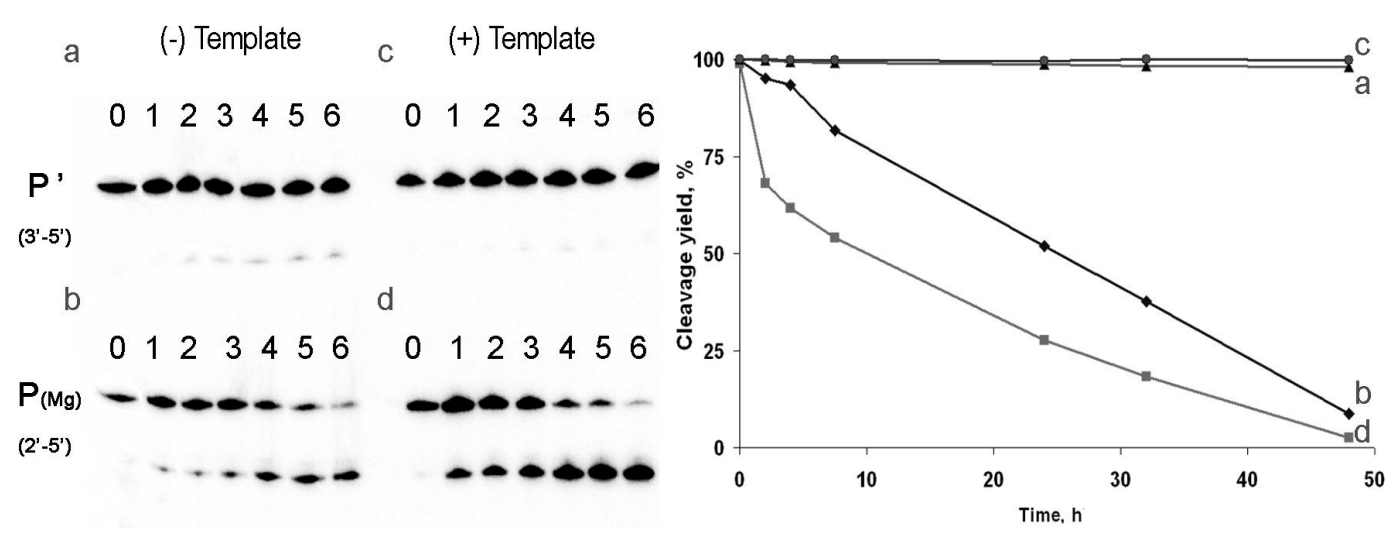

Fig. 5. Stability of isolated $3^{\prime}, 5^{\prime}$ and $2^{\prime}, 5^{\prime}$ RNA linkages within the $P^{\prime}(a, c)$ and $P(M g)(b, d)$ in the absence (a, b) and in the presence (c, d) of DNA-complement. The ligation products were incubated in $50 \mathrm{mM}$ Tris $\mathrm{pH} 9.0$ buffer containing $100 \mathrm{mM} \mathrm{Mg}^{2+}$ at $37^{\circ} \mathrm{C}$ for different time intervals: $0,2,4,7.5,24,32,48 \mathrm{~h}$ (A, lanes 0-7). (A) Autoradiograph of 15\% d-PAGE after separation of the cleavage products. (B) Secondary plot of the data shown in section A. The values of rate constants $\left(\mathrm{k}_{1}, \mathrm{~h}^{-1}\right)$ obtained from best-fit curves using first-order exponential kinetics equation are (a) $450 \times 10^{-4} \mathrm{~h}^{-1}$; (b) $5 \times 10^{-4} \mathrm{~h}^{-1}$; (c) $700 \times 10^{-4} \mathrm{~h}^{-1}$; (d) $<1 \times 10^{-5} \mathrm{~h}^{-1}$.

catalysis of the reaction proceeding possibly via increasing of nucleophilic properties of the attacking $5^{\prime}$-hydroxyl group, as it was shown earlier (Renz et al., 1971). $\mathrm{Mg}^{2+}$ ions (5 mM) accelerated the reaction in $\mathrm{pH}$-dependent manner and the catalytic ability of $\mathrm{Mg}^{2+}$ ion increased at high $\mathrm{pH}$. For metal ion-catalyzed reactions involving transformations of phosphodiester bonds, such $\mathrm{pH}$-dependence is well known (Pyle, 2002) and is explained by the following factors: i) activation of hydroxyl groups via increasing of the attacking oxygen nucleophilicity, ii) stabilization of the developing negative charge on the leaving oxygen group, iii) activation of phosphate center atom for nucleophilic attack through coordination to the non-bridging oxygen.

If a metal ion plays a role of catalyst in the ligation reaction, its activity should correlate with the Lewis acidity of the coordinated water molecules that is determined by the nature of the metal ion.

In the experiments with varying concentrations of metal ions, solubility limitations for the metal ions were neglected on purpose to have the general view on the metal ions behavior under reaction conditions that might mimic the prebiotic synthesis conditions.

At $\mathrm{pH} 7.2$, catalytic activity of the divalents increased in the order: $\mathrm{Mg}<\mathrm{Mn}<\mathrm{Co}$. The catalytic activity of the metal ions inversely correlates with $\mathrm{pKa}$ of metal-bound water molecules (here and after $\mathrm{pKa}_{w}$ ):12(Mg) $>10.7(\mathrm{Mn})>8.7$ (Co) (Kazakov et al., 1994). Since pH of the reaction buffer was lower than these $\mathrm{pKa}_{w}$ values, it indicates that the catalytic activity of the ions is proportional to concentration of the metal-bound hydroxide, which could participate in all three activation pathways mentioned above.

At $\mathrm{pH} 8.8$ another order of the catalytic activity of the metal ions is observed: $\mathrm{Mg}>>\mathrm{Mn}=\mathrm{Co}$. This can be ex- plained by formation of insoluble metal hydroxides. Effective concentration of metal ions in the reaction solution can be calculated using the values of the equilibrium solubility constants for the metal hydroxides. For example, the calculated values of effective concentration were about $1 \mathrm{mM}$ for $\mathrm{Mn}^{2+}$ ion at $\mathrm{pH} 8.8,5 \mathrm{mM}$ for $\mathrm{Zn}^{2+}$ ion at $\mathrm{pH} 7.2$ and $25 \mathrm{mM}$ for $\mathrm{Co}^{2+}$ ions at $\mathrm{pH}$ 7.2, and correlate with the positions of maxima of the curves ("yield" vs. $\left[\mathrm{Me}^{2+}\right]$ )(Fig. 3). At pH 8.8 the equilibrium concentrations of $\mathrm{Co}^{2+}, \mathrm{Zn}^{2+}, \mathrm{Pb}^{2+}$ are in micromolar range, therefore we observed no maxima in the concentration dependences at the concentrations used.

The maximal yields of ligation reaction were observed in the presence of $\mathrm{Mg}^{2+}$ at $\mathrm{pH} 8.8$ ), $\mathrm{Mn}^{2+}$ at $\mathrm{pH} 7.2$ and $\mathrm{Pb}^{2+}$ ions at $\mathrm{pH}$ 7.2. In the case of $\mathrm{Pb}^{2+}$ ion, we observed maximal reaction yield at concentration $0.5 \mathrm{mM}$ that corresponds to the competing formation of lead (II) chloride, but not hydroxide (which gives the ten-fold higher equilibrium concentration). For $\mathrm{Mn}^{2+}$ at $\mathrm{pH} 7.2$ and for $\mathrm{Mg}^{2+}$ at $\mathrm{pH}$ 8.8 , the maximal yield of ligation is observed at concentrations of the metals far below expected equilibrium concentrations of these metal ions under the conditions used $(0.7 \mathrm{M}$ and $0.15 \mathrm{M}$, respectively) (Fig. 2). Thus, decrease of ligation yield observed at higher metal concentrations can not be explained by hydroxide precipitation. We suggest that the observed effect can be caused by the enhanced cleavage of formed $2^{\prime}, 5^{\prime}$-bonds within double helix. These results demonstrate that metal ions, the main prebiotic catalysts, can significantly increase the yield of the nonenzymatic RNA ligation. 


\section{$4.2 \quad 2^{\prime}, 5^{\prime}$-linked product formation}

The isolated product of nonenzymatic ligation, $\mathrm{P}(\mathrm{Me})$, was resistant to ribonuclease $\mathrm{T} 1$ under the conditions where $3^{\prime}, 5^{\prime}$ bonds are completely cleaved by the enzyme. Since the ligation products $\mathrm{P}(\mathrm{Me})$ and $\mathrm{P}^{\prime}$ have no differences except for the forming phosphodiester bond, the result of comparative T1-probing can be attributed to the $2^{\prime}, 5^{\prime}$-bond formation in the nonenzymatic ligation products.

Preferential formation of one type of the linkages was described earlier (Rohatgi et al., 1996). 3', $5^{\prime}$-bonds were obtained in the template-directed ligation reaction of 10-nt and 7-nt oligoribonucleotides with pyrophosphate and imidazole leaving groups. In the presence of $100 \mathrm{mM} \mathrm{Mg}^{2+}$ at $\mathrm{pH} 9.0$, $3^{\prime}, 5^{\prime}$-phosphodiester bonds formed faster than $2^{\prime}, 5^{\prime}$-bonds and, once formed in the duplex context, were $>100$ times more stable against base hydrolysis (Rohatgi et al., 1996). Another example is the synthesis of dodecamer (A) $)_{5} \mathrm{~A}\left(2^{\prime}\right.$ $\left.5^{\prime}\right) \mathrm{A}_{5} \mathrm{Ap}$, which was formed at $24 \%$ yield by incubation of (A) $5 \mathrm{~A}>\mathrm{p}$ with two equivalents of poly(U) in ethylenediamine buffer at $\mathrm{pH} 8$, at $0^{\circ} \mathrm{C}$. The reaction appeared to occur within triple stranded complex $(\mathrm{A} * 2 \mathrm{U})$, the geometry of which was favorable for in-line displacement with the release of $3^{\prime}$ hydroxyl and $2^{\prime}, 5^{\prime}$-linkage formation (Usher et al., 1976). Thus, the origin of the observed regioselectivity can be the different stability of forming isomers or the relative orientation of the reactive groups. In model system we investigated the ribo-linkage is located in the DNA environment.

In order to elucidate the reason of $2^{\prime}, 5^{\prime}$-selectivity and to check the possible influence of DNA environment, we tested the stability of this type of linkage to alkaline hydrolysis, compared to that of the $3^{\prime}, 5^{\prime}$ ribo-linkages. $48 \mathrm{~h}$ incubation of the nonenzymatic ligation product, $\mathrm{P}(\mathrm{Mg})$, in the mild alkaline hydrolysis conditions $\left(100 \mathrm{mM} \mathrm{Mg}^{2+}, \mathrm{pH} 9.0,37^{\circ} \mathrm{C}\right)$ resulted in complete cleavage with the rate similar to that of the $2^{\prime}, 5^{\prime}$-linked isolated RNA bonds reported by Szostak (Rohatgi et al., 1996). This confirms that the $2 /, 5 /$ ribo-linkages in the DNA environment demonstrate similar stability, as reported for RNA oligonucleotides: in the presence of complementary strand $2^{\prime}, 5^{\prime}$-linkages were $10^{3}$ times less stable than $3^{\prime}, 5^{\prime}$-linkages.

Since the ligation product containg $3^{\prime}, 5^{\prime}$-phosphodiester bonds has a greater stability and haven't been formed, one can suggest that it had not formed at all during the reaction.

The rate of the transesterification reaction depends on the probability of the in-line conformation in the transition state, when forming O-P and cleaving $\mathrm{P}-\mathrm{O}$ bonds are placed on the opposite sides of the phosphorus atom. Similarly, the rate of the ligation reaction depends on the probability of the in-line attack by the $5^{\prime}$-oxygen atom and the type of formed linkage is determined by the direction of attack - whether $2^{\prime}$ or $3^{\prime}$ oxygen atom is on the opposite side. Since the transesterification reaction of $2^{\prime}, 5^{\prime}$-phosphodiester bonds, resulting in formation of $2^{\prime}, 3^{\prime}$-cyclic phosphate, is in the equilibrium with the ligation reaction, we conclude that the terminal $2^{\prime}, 3^{\prime}$ cyclic phosphate participates in reaction in single spatial orientation, when $5^{\prime}$-attacking oxygen is in-line conformation with $3^{\prime}$-cleaving O-P bond of cyclic phosphate. This orientation is similar to that proposed for the ligation in the triple helix by Usher et al. (1976).

\subsection{Possible prebiotic role and actual environmental mean-} ing of $2^{\prime}, 5^{\prime}$-linked RNAs

RNA molecules existing in the environment today contain exclusively of $3^{\prime}, 5^{\prime}$-phosphodiester linkages, due to the regiospecificity of an enzymatic synthesis. The only naturally occurring linear RNAs with $2^{\prime}, 5^{\prime}$-linkages are the $2^{\prime}, 5^{\prime}$-oligoadenylates, synthesized by double-stranded RNAdependent synthetases (see Player et al., 1998 and references in it).

The template-directed ligation reaction in the studied systems with the participation of the terminal $2^{\prime}, 3^{\prime}$-cyclic phosphates produced mostly $2^{\prime}, 5^{\prime}$-phosphodiester bonds and no evidences that these reactions could give significant contribution to the creation of naturally occurring RNA molecules, containing $3^{\prime}, 5^{\prime}$-phosphodiester bonds was observed. However, the prebiotic environment of RNA world had apparently to have the conditions, suitable for the existence of the double-stranded complexes, since it is required for the preservation and protection of $3^{\prime}, 5^{\prime}$-RNA linkages from the degradation.

The ligation reaction in the absence of the complementary template provides less conformational restrictions for the orientation of the reactants. The reactive groups are not approached as in the presence of the template, but the probability of their reaction could be high enough in some prebiotic conditions - e.g. concentration by evaporation, adsorption or formation of eutectic solutions. It was shown that selfpolymerization of $\mathrm{A}>\mathrm{p}$ in high-concentrated solutions and in the dry state results in the formation of phosphodiester linkages with ratio of $3^{\prime}, 5^{\prime} / 2^{\prime}, 5^{\prime}$ more than 1,5 (Verlander et al., 1973). Recently the ligation of hairpin ribozyme substrates, one of which contained $2^{\prime}, 3^{\prime}$-cyclic phosphate, under eutectic conditions was reported. The reaction was catalyzed by small structural fragments of the hairpin ribozyme and resulted in preferential $3^{\prime}, 5^{\prime}$-linkage formation (Vlassov et al., 2004).

Though $2^{\prime}, 5^{\prime}$-linkage seems to be the more likely outcome of the template-directed ligation reaction with participation of $2^{\prime}, 3^{\prime}$-cyclic phosphates, its formation should be considered as a detour rather than an impasse for some reasons. First, the transesterification reaction produces the cyclic phosphate and returns the system in the initial state; second, recent experiments demonstrate that oligoribonucleotides, containing $2^{\prime}, 5^{\prime}$-linkages are active in template-directed oligomerization reactions and could serve as a template also (Ertem et al., 1996; Sawai et al., 1998). 
Recently, the self-ligation was shown to occur inside the Peach latent mosaic viroid (PLMVd) via the interaction of $2^{\prime}, 3^{\prime}$-cyclic phosphate and $5^{\prime}$-hydroxyl group (Lafontaine et al., 1995). The formed linkages were almost solely $2^{\prime}, 5^{\prime}$ $(>96 \%)$ and were shown to stabilize the replicational circular templates of viroid. Since the viral reverse transcriptase is able to read through a $2^{\prime}, 5^{\prime}$-linkage, its presence in the viroid structure results in a significant advantage in terms of viroid viability, protecting the viroid integrity (Cote et al., 2001). This result represent an unique example of the utilization of $2^{\prime}, 5^{\prime}$-linkage, produced in the self-ligation reaction from $2^{\prime}, 3^{\prime}$-cyclic phosphate. Thus, it is tempting to speculate that similar ligation reactions with formation of $2^{\prime}, 5^{\prime}$-linkages could proceed in other molecular systems, containg RNA molecules, providing not only stabilization, but a creation of new RNA molecules, as it was proposed by Chetverin et al. (1997).

Acknowledgements. We thank M. N. Repkova, A. G. Venyaminova, and D. V. Pyshniy for the synthesis of chimerical oligos, we wish also to thank Alexander Vlassov for helpful comments. This work was supported by grants from RFBR (SS-1384.2003.4) and from the program of Presidium of RAS "Origin of life and evolution of the biosphere".

Edited by: F. Westall

\section{References}

Chetverin, A. B.: The puzzle of RNA recombination, FEBS Lett., 460, 1-5, 1999.

Chetverin, A. B., Chetverina, H. V., Demidenko, A. A., and Ugarov, V. I.: Nonhomologous RNA recombination in a cell-free system: evidence for a transesterification mechanism guided by secondary structure, Cell., 88, 503-513, 1997.

Cote, F., Levesque, D., and Perreault, J. P.: Natural $2^{\prime}, 5^{\prime}$ phosphodiester bonds found at the ligation sites of peach latent mosaic viroid, J. Virol., 75, 19-25, 2001.

Dahm, S. C., Derrick, W. B., and Uhlenbeck, O. C.: Evidence for the role of solvated metal hydroxide in the hammerhead cleavage mechanism, Biochem., 32, 13 040-13 045, 1993.

Ertem, G. and Ferris, J. P.: Synthesis of RNA oligomers on heterogeneous templates, Nature, 379, 238-240, 1996.

Flynn-Charlebois, A., Prior, T. K., Hoadley, K. A., and Silverman, S. K.: In vitro evolution of an RNA-cleaving DNA enzyme into an RNA ligase switches the selectivity from $3^{\prime}-5^{\prime}$ to $2^{\prime}-5^{\prime}$, J. Am. Chem. Soc., 125, 5346-5350, 2003.

Flynn-Charlebois, A., Wang, Y., Prior, T. K., Rashid, I., Hoadley, K. A., Coppins, R. L., Wolf, A. C., and Silverman, S. K.: Deoxyribozymes with $2^{\prime}-5^{\prime}$ RNA ligase activity, J. Am. Chem. Soc., 125, 2444-2454, 2003.

Hampel, A. and Cowan, J. A.: A unique mechanism for RNA catalysis: the role of metal cofactors in hairpin ribozyme cleavage, Chem. Biol., 4, 513-517, 1997.
Hertel, K. J., Herschlag, D., and Uhlenbeck, O. C.: A kinetic and thermodynamic framework for the hammerhead ribozyme reaction, Biochem., 33, 3374-3385, 1994.

Jeoung, Y. H., Kumar, P. K., Suh, Y. A., Taira, K., and Nishikawa, S.: Identification of phosphate oxygens that are important for self-cleavage activity of the HDV ribozyme by phosphorothioate substitution interference analysis, Nucleic. Acids Res., 22, 37223727, 1994.

Kazakov, S. A. and Hecht, S. M.: Encyclopedia of Inorganic Chemistry, Wiley, NY, 1994.

Lafontaine, D., Beaudry, D., Marquis, P., and Perreault, J. P.: Intraand intermolecular nonenzymatic ligations occur within transcripts derived from the peach latent mosaic viroid, Virology, 212, 705-709, 1995.

Lutay, A. V., Chernolovskaya, E. L., Zenkova, M. A., and Vlassov, V. V.: Nonenzymatic Template-Dependent Ligation of $2^{\prime}, 3^{\prime}$ Cyclic Phosphate-Containing Oligonucleotides Catalyzed by Metal Ions, Doklady Biochemistry and Biophysics, 401, 163166, 2005.

Player, M. R. and Torrence, P. F.: The 2-5A system: modulation of viral and cellular processes through acceleration of RNA degradation, Pharmacol. Ther., 78, 55-113, 1998.

Pyle, A. M.: Metal ions in the structure and function of RNA, J. Biol. Inorg. Chem., 7, 679-690, 2002.

Renz, M., Lohrmann, R., and Orgel, L. E.: Catalysts for the polymerization of adenosine cyclic $2^{\prime}, 3^{\prime}$-phosphate on a poly (U) template, Biochim. Biophys. Acta, 240, 463-471, 1971.

Rohatgi, R., Bartel, D. P., and Szostak, J. W.: Nonenzymatic, template-directed ligation of oligoribonucleotides is highly regioselective for the formation of $3^{\prime}-5^{\prime}$ phosphodiester bonds, J. Am. Chem. Soc., 118, 3340-3344, 1996.

Rohatgi, R., Bartel, D. P., and Szostak, J. W.: Kinetic and mechanistic analysis of nonenzymatic, template-directed oligoribonucleotide ligation, J. Am. Chem. Soc., 118, 3332-3339, 1996.

Santoro, S. W. and Joyce, G. F.: Mechanism and utility of an RNAcleaving DNA enzyme, Biochem., 37, 13 330-13 342, 1998.

Sawai, H., Totsuka, S., Yamamoto, K., and Ozaki, H.: Nonenzymatic, template-directed ligation of $2^{\prime}-5^{\prime}$ oligoribonucleotides, Joining of a template and a ligator strand, Nucleic. Acids Res., 26, 2995-3000, 1998.

Soukup, G. A. and Breaker, R. R.: Relationship between internucleotide linkage geometry and the stability of RNA, Rna., 5, 1308-1325, 1999.

Usher, D. A. and McHale, A. H.: Nonenzymatic joining of oligoadenylates on a polyuridylic acid template, Science, 192, 53-54, 1976.

Verlander, M. S., Lohrmann, R., and Orgel, L. E.: Catalysts for the self-polymerization of adenosine cyclic $2^{\prime}, 3^{\prime}$-phosphate, J. Mol. Evol., 2, 303-316, 1973.

Vlassov, A. V., Johnston, B. H., Landweber, L. F., and Kazakov, S. A.: Ligation activity of fragmented ribozymes in frozen solution: implications for the RNA world, Nucleic. Acids Res., 32, 29662974, 2004. 